
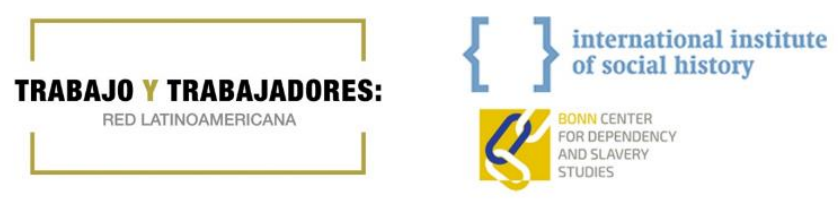

\title{
CRÍTICA DE LIBROS
}

Oscar De la Torre, The People of the River: Nature and Identity in Black Amazonia, 1835-1945. (Chapel Hill: The University of North Carolina Press, 2018), 242 pp.

El historiador Oscar de la Torre analiza la historia de las comunidades cimarrones en la Amazonía brasilera, en la frontera del Pará, en el periodo de la post-esclavitud. Los cimarrones, conocidos como mocambos en la Amazonía, establecieron colonias en las periferias de las sociedades esclavistas. En general, los estudios sobre esta área, tan concentrados en la presencia portuguesa y la producción azucarera, habían considerado que en la Amazonía se habían dado cambios históricos y económicos poco trascendentales. Los cambios más importantes habrían tenido lugar con el auge de la goma. Sin embargo, al cambiar la mirada y hacer de las comunidades campesinas negras el centro de la historia, De la Torre revela la centralidad que tuvieron las comunidades de esclavos fugitivos en el desarrollo de una importante economía nacional.

El libro combina herramientas de la historia social, la historia medioambiental y la historia oral. Con estas herramientas, el autor demuestra que no podemos entender la identidad negra campesina sin analizar las referencias de estos campesinos al paisaje y a su relación con el espacio. Muchos de los estudios de los quilombos subrayaron la construcción identitaria de los campesinos basada en su identidad racial. Sin embargo, De la Torre rescata la importancia que tuvieron la ecología y el paisaje, la dimensión simbólica y material del paisaje como elementos cruciales para la construcción de su identidad. Cuando habla de paisaje, el autor se refiere tanto a los lugares físicos como a las narrativas que la gente formula sobre ellos. De la Torre analiza, por tanto, las conexiones entre el mundo natural y el proceso histórico.

El autor utiliza creativamente la tradición oral para entender la historia de lucha y resistencia de los cimarrones. En el capítulo dos, por ejemplo, 
trascribe el mito de la gran serpiente, cuyo relato oyó de un líder campesino en la década de 1990. El mito hablaba de una enorme fiera que vivía en las cascadas. En la reconstrucción del mito, De la Torre apunta que la serpiente simbolizaba la feroz, violenta y potencialmente mortal fuerza que se oponía al deseo de los mocamberos de crear un espacio de autonomía. La serpiente expresaba en términos mitológicos el poder de los hacendados, dueños de plantaciones, quienes contaban con apoyo militar para capturar esclavos fugitivos. La gran serpiente representaba el obstáculo entre los fugitivos y su libertad. De la Torre añade que no es sorprendente que los mocamberos escogieran la serpiente para simbolizar el poder amenazante de los poseedores de esclavos. La serpiente es un símbolo común en la mitología de los pueblos del oeste del África. El mito de la serpiente muestra, por tanto, la manera en que los esclavos fugitivos utilizaron elementos culturales del África para narrar su historia en el periodo de la esclavitud y post-esclavitud en el Brasil.

$\mathrm{El}$ autor también analiza la manera en la que los cimarrones experimentaron la abolición de la esclavitud. No fue como un evento específico sino como resultado de la creciente migración que empezó a llegar a partir de la "muerte de la gran serpiente". Otro aporte importante del libro tiene que ver con el concepto de economía paralela. De la Torre propone que los esclavos y los cimarrones generaron una economía basada en la producción de algodón, cacao y café, que no estuvo sujeta a los límites de la plantación. De acuerdo con el autor, desde 1840 hasta 1870 -cuando comenzó el auge de la gomaesta región fue testigo de un crecimiento económico que no se explica si no es a través de analizar la economía impulsada por las comunidades negras campesinas.

En 1988, año en que se rememoraba el centenario de la abolición de la esclavitud, la Constitución brasileña reconoció por primera vez el derecho de los descendientes de quilombos a recibir tierras del Estado. Aunque esta medida parecía - en gran medida- simbólica, pues se pensaba que muchas de estas comunidades se habían disuelto o desaparecido, para sorpresa de muchos el país testificó en los noventa la emergencia de miles de demandas de comunidades negras exigiendo al Estado el reconocimiento de su identidad y su derecho colectivo a las tierras. Las demandas que emergieron en los noventa son inexplicables, nos dice De la Torre, si no entendemos la relación histórica y política de estas comunidades con la geografía, nutrida por la historia de conflicto y resistencia con los hacendados en los siglos XIX y XX.

CARMEN SOLIZ

University of North Carolina at Charlotte soliz.urrutia@uncc.edu 